\title{
A Linguistic Study of Courtship as a Rule-bound Social Institution in Pride and Prejudice
}

\author{
Akram Pouralifard, Moslem Ahmadi*
}

Faculty of Persian and Foreign Languages, Tabriz University, 29 Bahman Boulevard, Tabriz 51666-14766, Iran

Corresponding Author: Moslem Ahmadi, E-mail: moslemahmadiapril1992@gmail.com

\section{ARTICLE INFO}

Article history

Received: July 10, 2017

Accepted: October 01, 2017

Published: October 31, 2017

Volume: 8 Issue: 5

Advance access: October 2017

Conflicts of interest: None

Funding: None

\begin{abstract}
The focus of this research is in the area of the relationship between linguistics and the Victorian literature. Such a study is important in order to demonstrate how the masterpieces of Victorian literature possess the potential to be studied according to the principles of linguistics and how the motives behind many characters' activities can be determined by recourse to linguistics. The findings from this research provide evidence that all human activities follow the same rules which all the human languages are based on and according to which they all function due to their common root in the human mind. The main conclusion drawn from this study is that linguistic principles can constitute a great methodology for determining the real motives behind many activities done by the humans. This paper recommends that linguistic principles can be an excellent methodology by means of which the researchers can study the literary works of other eras in the English literature.
\end{abstract}

\section{Key words:}

Linguistics,

Literature,

Motives,

Characters,

Activities,

Mind

\section{INTRODUCTION}

The courtship seems to follow a strict and regular rule in Jane Austen's novels. One of her novels in which this rule is most tangible is Pride and Prejudice. At the beginning of Pride and Prejudice, Jane Austen proclaims courtship as the main theme of her novel with her famous verbal irony, "it is a truth universally acknowledged, that a single man in possession of a good fortune must be in want of a wife" (Austen, 1853). The endeavours undertaken by the different male and female characters for a successful marriage follow regular rules based on their gender. This is what makes this novel a suitable case for this study. Accordingly, the present study aims to find out if the rule-bound courtship represented in the aforementioned novel can be studied according to a rulebound system such as linguistics. To facilitate the process of achieving this aim, the overall research aim is divided into two main goals. On one hand, this study intends to find out whether the male and female patterns of behaviour in courtship can be studied according to identical linguistic rules or not. On the other hand, this study intends to find out why two different phenomena such as courtship and linguistics follow similar rules.

\section{DISCUSSION}

Before addressing the main subject of this paper, a preliminary introduction into two important linguistic concepts is a sine qua non for a better understanding of the present discussion. Roman Jakobson developed a widely used distinction between the rules governing paradigmatic relations and syntagmatic relations (Abrams \& Harpham, 2014). Each item in language is in a paradigmatic relationship with the other items which have the potential to be substituted for it like the relationship between the two words cat and dog (McArthur, 1992). On the contrary, syntagmatic relations are not concerned with concepts but result in the real co-occurrence of terms in a specific setting (Peters \& Weller, 2008). Based on the above-mentioned definition for paradigmatic relationship, the items are in a vertical relationship with each other. Therefore, these items can be replaced by other items without any damage to the overall structure and meaning of a sentence. On the contrary, the above-mentioned definition for syntagmatic relations makes clear that the terms in a specific setting are in a horizontal relationship with each other. Therefore, the rules concerning the co-occurrence of terms in a specific setting cannot be changed. Some researchers 
have argued that the paradigmatic and syntagmatic relations are not limited to language and that these two types of relations can be applied to other domains which have nothing to do with language. A social institution such courtship can be considered one of these domains. Prior to addressing the paradigmatic and syntagmatic relations of courtship in Pride and Prejudice, I intend to explain how paradigmatic and syntagmatic relations function in courtship. Human evolutionary psychological studies indicate that for mate choice men rate female pulchritude higher than women rate masculine appearance (Grammer et al., 2003). Similarly, men's social status is a significant consideration in women's selections of and predilections for connubial mates (Geary et al., 2004). Accordingly, women's pulchritude and men's social status are syntagmatic relations of courtship, i.e., they are fixed and unchangeable conditions for marriage. On the contrary, the men and women engaged in courtship are in a paradigmatic relation, i.e., they can be replaced by other men and women who own better syntagmatic conditions for courtship.

Subsequent to single and rich Bingley's arrival at his new mansion called Netherfield Park, the news spreads throughout neighbourhood. Mrs. Bennet tells Mr. Bennet since Mr. Bingley is wealthy and single, he can make a brilliant spouse for one of their five daughters. Mrs. Bennet's words demonstrate that wealth is a necessary condition which a man must have to espouse one of their daughters. Therefore, Mr. Bingley's wealth functions as the syntagmatic condition of courtship and it can lead to the co-occurrence of Mr. Bingley and one of the five Bennet sisters under one roof with its horizontal nature. Mr. Bennet is one of the first men who pays Mr. Bingley a visit. All the women in Mr. Bennet's house become excited after hearing about Mr. Bennet's visit to Mr. Bingley. Accordingly, the paradigmatic rule of courtship, by virtue of its vertical nature, puts Mr. Bingley in a potential suitor's position. Lady Lucas' words about Mr. Bingley's young age, good looks, agreeableness, and his presence at the next assembly makes the Bennet ladies seize the next assembly as an opportunity to obtain Mr. Bingley's heart. Accordingly, Mr. Bingley's wealth continues to bring Mr. Bingley and one of the five Bennet sisters together like the appropriate words in a sentence, thereby implying that the syntagmatic relations are fixed and unchangeable. During returning Mr. Bennet's visit, Mr. Bingley hopes to see the girls of whose pulchritude he has heard much. Mr. Bingley's misplaced hope demonstrates that pulchritude is a necessary condition which a girl must have to espouse him. Therefore, the Bennet girls' pulchritude functions as the syntagmatic condition of courtship and it can lead to the co-occurrence of Mr. Bingley and one of the five Bennet sisters under one roof with its horizontal nature. During the assembly, Jane Austen confirms Lady Lucas' words by delineating Mr. Bingley's good looks and easy going manners. Jane Austen also describes Mr. Bingley's friend Mr. Darcy as richer and handsomer than Mr. Bingley. Thus, she, by virtue of the vertical nature of the paradigmatic rule of courtship, puts Mr. Darcy in a potential suitor's position as well. Mr. Darcy's manners turn "the tide of his popularity". This demonstrates the vertical nature of the paradigmatic rule of courtship which can remove someone from a potential suitor's position. Elizabeth Bennet overhears Mr. Darcy's sentence addressed to Mr. Bingley regarding her older sister, Jane, "You are dancing with the only handsome girl in the room". Mr. Bingley replies, "Oh, she is the most beautiful creature I ever beheld". Accordingly, Jane Bennet's immense pulchritude, by virtue of the vertical nature of the paradigmatic rule of courtship, puts Jane in a potential wife's position. After Mr. Bingley tries to make Mr. Darcy dance with Elizabeth, Mr. Darcy says, "She is tolerable, but not handsome enough to tempt me". Since her sister outstrips her in beauty, Elizabeth, according to the syntagmatic rule of courtship, cannot supersede her sister. Amidst the conversation between Elizabeth and Jane, Jane reveals her infatuation with Mr. Bingley. Therefore, Mr. Bingley's wealth and Jane's pulchritude, by virtue of the syntagmatic rule of courtship, have managed to bring them both together under one roof. This is also evident in Charlotte Lucas' words that she overheard Mr. Bingley's admiration for Jane's pulchritude. In the following, we see that Mr. Darcy begins to admire Elizabeth's pulchritude. Therefore, Elizabeth Bennet's pulchritude functions as the syntagmatic rule of courtship and it can lead to the co-occurrence of Mr. Darcy and Elizabeth Bennet under one roof with its horizontal nature, thereby putting her in a potential wife's position by virtue of the vertical nature of the paradigmatic rule of courtship. This potential wife's position to Elizabeth Bennet's advantage continues during Elizabeth's visit to the ill Jane at Netherfield, especially in Mr. Darcy's "admiration of the brilliancy which exercise had given to her complexion". Remembering Mr. Darcy's initial criticism of her appearance, Elizabeth doesn't consider Mr. Darcy's constant look at her as a sign of interest and even refuses Mr. Darcy's request for a dance to avoid being mocked by Mr. Darcy. Mr. Bennet's cousin called Mr. Collins comes to visit the Bennets. Since he is a pastor and not as wealthy as Mr. Bingley or Mr. Darcy, the Bennet girls don't consider him as a potential husband. Accordingly, Mr. Collins lacks the syntagmatic condition of courtship called wealth. This cannot lead to the co-occurrence of Mr. Collins and one of the five Bennet sisters under one roof with its horizontal nature. This is especially conspicuous where Mrs. Bennet precludes Mr. Collins from developing an interest in Jane. In chapter nineteen, Elizabeth Bennet also rejects Mr. Collins' proposal of marriage due to his position as a priest and not a wealthy upper-class man. During a supper party at the Philips' house, Mr. Wickham tells Elizabeth how Mr. Darcy ignored his father's request concerning Mr. Wickham's position as a clergyman on the Darcy estate. At the end of the party, Elizabeth becomes infatuated with Mr. Wickham. At a ball, Elizabeth sarcastically refers to Mr. Darcy's bad treatment of Mr. Wickham while she's dancing with Mr. Darcy. As a result, Mr. Wickham jeopardizes Mr. Darcy's position as a potential husband in Elizabeth's future life by shifting Elizabeth's attention from Mr. Darcy's wealth to his poor comportment. This reflects the substitutable nature of the paradigmatic rule of courtship in which one person can be substituted with another person. Having been admonished to be more serious about her relationship with 
Mr. Wickham by Mrs. Gardiner, Elizabeth says that Mr. Wickham can't be an excellent choice for marriage due to his financially poor state. As it was the case with Mr. Collins, Mr. Wickham's lack of the syntagmatic condition of courtship, i.e., wealth cannot lead to the co-occurrence of Mr. Wickham and Elizabeth Bennet under one roof with its horizontal nature.Mr. Darcy shows up again and Charlotte thanks Elizabeth for dragging Mr. Darcy to their house. A week later at Rosings, Colonel Fitzwilliam's flirtation with Elizabeth Bennet makes Mr. Darcy look at them with curiosity. Mr. Darcy's curious look confirms that he has returned to see Elizabeth Bennet. To put it another way, Elizabeth's pulchritude, i.e., her syntagmatic condition for courtship has brought Mr. Darcy back to Elizabeth Bennet. This is also obvious in Charlotte's words when Mr. Darcy calls on Elizabeth and Charlotte a while later, "My dear Eli$\mathrm{za}$, he must be in love with you, or he would never have called on us in this familiar way". As a result, Mr. Darcy keeps haunting Elizabeth Bennet during her rambles within the park. At long last, Mr. Darcy finds the courage to express his love to Elizabeth Bennet. But Elizabeth Bennet rejects Mr. Darcy's declaration of love due to his disgusting comportment and condescending attitude towards her family. This is where Mr. Darcy's poor comportment and condescending attitude towards the others downplays his wealth, i.e., his syntagmatic condition for courtship. In a letter, Mr. Darcy tells Elizabeth Bennet how Mr. Wickham exchanged his position as a priest on the Darcy estate for three thousand pounds by which he could study law, but Mr. Wickham squandered all the money instead of spending it for a degree in law. Having become broke, Mr. Wickham tried to get back his position as priest on the Darcy estate. Mr. Darcy's refusal of his entreaty makes Mr. Wickham turn his attention to Mr. Darcy's younger sister called Georgiana, but Mr. Darcy prevents her elopement with Mr. Wickham. Thus, Mr. Darcy tries to foreground his syntagmatic condition for courtship, i.e., his wealth by exculpating himself from Mr. Wickham's accusations. Mr. Darcy's letter apprises Elizabeth Bennet of her prejudice. As a result, Elizabeth finally loses all concern for Mr. Wickham. Therefore, Mr. Darcy succeeds in regaining his position as a potential husband in Elizabeth Bennet's future life according to the paradigmatic rule of courtship. During Elizabeth Bennet's visit to Pemberley, Mr. Darcy's estate astonishes her. Jane Austen (1853) beautifully limns Elizabeth Bennet's reaction to Mr. Darcy's estate:

It was a large, handsome, stone building, standing well on rising ground, and backed by a ridge of high woody hills; and in front a stream of some natural importance was swelled into greater, but without any artificial appearance. Its banks were neither formal nor falsely adorned. Elizabeth was delighted. She had never seen a place for which nature had done more, or where natural beauty had been so little counteracted by an awkward taste. They were all of them warm in their admiration; and at that moment she felt that to be mistress of Pemberley might be something! (p. 212)

So this visit makes Elizabeth Bennet attracted to $\mathrm{Mr}$. Darcy's syntagmatic condition for marriage, i.e., his wealth. During Elizabeth Bennet's sudden encounter with Mr. Darcy, Mr. Darcy's perfect civility further changes everything to Mr. Darcy's advantage. After Mr. Bingley and Mr. Darcy return to Netherfield and visit the Bennets, Jane Bennet's pulchritude rekindles Mr. Bingley's admiration. This initial admiration is followed by Mr. Bingley's proposal to Jane Bennet. After a while, Mr. Darcy reveals his love to Elizabeth Bennet during a private conversation.

\section{CONCLUSION}

The analysis done in this paper demonstrates that the rulebound courtship represented in Pride and Prejudice can be studied according to a rule-bound system such as linguistics. It also reveals that male and female patterns of behaviour in courtship represented in this novel can be studied according to identical linguistic rules. This is due to the fact that the male and female characters show these patterns of behaviour to achieve specific goals determined by their gender, i.e., pulchritude and wealth. Finally, it can be said since language and courtship both originate in the human mind, they follow similar rules. Therefore, they can be studied according to similar principles. This rule applies to other human activities such as working. Whereas making money is the syntagmatic rule of working, i.e., stable and fixed, the kind of job to earn money is the paradigmatic rule of working, i.e., unstable and subject to change.

\section{REFERENCES}

Abrams, M. H., \& Harpham, G. G. (2014). A Glossary of Literary Terms. $\left(11^{\text {th }}\right.$ ed.). Boston: Wadsworth Cengage Learning.

Austen, J. (1853). Pride and Prejudice. London: Richard Bentley.

Geary, D. C., Vigil, J., \& Byrd, J. (2004) Evolution of Human Mate Choice. The Journal of Sex Research. 41(1). 27-42.

Grammer, K., Fink, B., Møller, A. P., \& Thornhill, R. (2003). Darwinian aesthetics: sexual selection and the biology of beauty. Biol. Rev. 78(3). 385-407.

McArthur, T. (1992). The Oxford Companion to the English Language. Oxford: Oxford University Press.

Peters, Isabella, \& Weller, K. (2008). Paradigmatic and Syntagmatic Relations in Knowledge Organization Systems. Information-Wissenschaft und Praxis 59(2): 100-107. 